\title{
A TEORIA DA APARÊNCIA NO DIREITO DFAMÍLIA: BREVES CONSIDERAÇÕES SOBRE A NECESSÁRIA DISTINÇÃO ENTRE O CASAMENTO PUTATIVO E O CASAMENTO APARENTE
}

\section{THE APPEARANCE THEORY IN FAMILY LAW: BRIEF CONSIDERATIONS ON THE NECESSARY DISTICTION BETWEEN PUTATIVE AND APPARENT MARRIAGE}

\author{
${ }^{1}$ César Augusto de Castro Fiuza \\ ${ }^{2}$ Mateus Bicalho de Melo Chavinho
}

\section{RESUMO}

A teoria da aparência é um importante instituto doutrinário, engendrado por juristas e estudiosos alemães, italianos e franceses, com a finalidade de proteger a boa-fé e a confiança das pessoas nas relações jurídicas privadas que se formam constantemente na sociedade. A sua aplicação, nos dias atuais, ocorre nos diversos ramos do Direito, dentre os quais, no Direito de Família, como exemplificado pelo instituto do casamento aparente. O problema enfrentado versa sobre a necessária diferenciação doutrinária e prática entre os institutos do casamento putativo e do casamento aparente no Direito Privado brasileiro, após a análise histórica e analítica de ambos. O método utilizado consistiu em pesquisa bibliográfica acerca do tema e no estudo de casos judiciais específicos, aplicando-se a dedução para as conclusões.

Palavras-chave: Teoria da aparência, Direito de família, Casamento putativo, Casamento aparente

\section{ABSTRACT}

The appearance theory is an important doctrinal institute, concocted by German, Italian and French legal scholars, in order to protect peoples good faith and trust in private legal relations, constantly being formed in society. Its application, nowadays, occurs in many areas of law, among them, in family law, as exemplified by the apparent wedding institute. The problem of the present essay deals with the necessary doctrinal and practical differentiation between the institutes of putative marriage and apparent wedding in Brazilian private law, after an historical and analytical analysis of both. The applied method consisted of bibliographical research on the subject and the study of specific court cases. The conclusions were a result of deduction.

Keywords/Palabras-claves/Mots-clés: Appearance theory, Family law, Putative marriage, Apparent wedding

\footnotetext{
${ }^{1}$ Doutor em Direito pela Universidade Federal de Minas Gerais - UFMG, Minas Gerais, MG. Professor na Pontifícia Universidade Católica de Minas Gerais, PUC Minas, Minas Gerais, MG, (Brasil). E-mail: cesarfiuza@gmail.com.

${ }^{2}$ Doutorando em Direito pela Pontifícia Universidade Católica de Minas Gerais, PUC Minas, Minas Gerais, MG. Juiz da 2a Turma Recursal de Contagem do Tribunal de Justiça de Minas Gerais, TJMG, Minas Gerais, MG, (Brasil). E-mail: mateusbmc@uol.com.br.
} 


\section{INTRODUÇÃO: A EVOLUÇÃO DA INSTITUIÇÃO DO CASAMENTO E SUA RELEITURA E REVISÃO NA ORDEM JURÍDICA CIVIL-CONSTITUCIONAL BRASILEIRA}

Inúmeras instituições identificadas na sociedade contemporânea, na realidade, já existem desde o início da história da humanidade. Dentre elas, a família, que pode ser considerada uma das mais antigas, tendo evoluído enormemente ao longo do tempo, em face das aspirações e mudanças ocorridas na própria sociedade. Essa evolução ocorreu e continua a ocorrer, podendo- se afirmar que as mudanças na sociedade são o elemento informador da evolução da própria família (FACHIN, 2001, p. 79).

A palavra "família", classificada como substantivo feminino, não possui apenas um significado no dicionário. Pode ser definida como um grupo de pessoas que vivem sob o mesmo teto, ou que provém de um mesmo tronco ancestral. Tal fato reflete a dificuldade em torno de um único conceito, uma vez que a própria instituição familiar não se manteve estática, como que congelada no tempo-espaço.

No período romano mais antigo, a família era uma associação religiosa, ritualística e sacralizada, tendo uma função importante de preservar o culto dos mortos e dos antepassados, o que fazia com que houvesse um vínculo entre seus membros (COULANGES, 1950, p. 55).

Naquela época, no contexto da estrutura familiar, era marcante a autoridade da figura do paterfamilias, como era denominado o ascendente comum mais velho e com soberania sobre todos os descendentes no contexto de uma estrutura hierarquizada e patriarcal. Na figura do paterfamilias romano, acumulavam-se as funções de chefe religioso, proprietário e julgador de todos os conflitos que eventualmente existissem no âmbito familiar.

Quando se iniciou a expansão do Império Romano, em período posterior (século II a.C.), o fortalecimento do Estado fez com que diminuísse o poder do paterfamilias em favor de um Estado incipiente, que teve o monopólio da justiça, fazendo com que ao chefe familiar fossem atribuídos os deveres de zelar, educar e cuidar dos familiares e do patrimônio. Segundo Fernanda Pessanha do Amaral Gurgel (2012, p. 33), "se, de um lado, o exercício do 'pátrio poder' gerava certas faculdades e prerrogativas, ficou estabelecido, em contrapartida, que a figura da autoridade parental passaria a assumir os encargos relacionados à manutenção, criação e proteção da prole".

Todavia, foi com o fortalecimento do cristianismo, que a Igreja Católica passou a influenciar, através dos cânones, ${ }^{1}$ e também a reger normativamente, a conformação da estrutura 
familiar, principalmente, por meio da instituição do casamento, como ritual solene, com as características de um contrato, que marcava a união do homem e da mulher, pelo acordo de vontades, o que foi marcante durante toda a Idade Média, e até bem recentemente, no Brasil.

O posterior movimento de codificação oitocentista, com aspirações marcadamente individualistas, influenciado pelos ideais iluministas de igualdade e liberdade, preocupou-se em dotar o indivíduo de liberdade, com menos intervenção do Estado na esfera privada, e em mitigar os privilégios da nobreza, o que interessou muito à classe burguesa em franca ascensão no sistema capitalista em formação.

O patrimonialismo era uma característica da denominada religião doméstica existente. Segundo Renata Almeida e Walsir Edson Rodrigues Júnior (2012, p. 7), in verbis: "antes a família justificava-se para manter o culto e, em vista disso, valia-se da propriedade privada. Já nesse novo momento histórico, a família formava-se para a aquisição do patrimônio. Alterou-se o escopo, tornando fim o que era simples meio."

No Brasil, até o advento da República, em 1889, por influência direta das legislações portuguesas e também da Igreja, somente existia o casamento religioso, tanto para os católicos como para os não católicos. O casamento civil somente surgiu no Brasil em 1891 (DIAS, 2007, p.137).

O Código Civil de 1916, fortemente influenciado pelo liberalismo burguês que marcou toda a Europa nos períodos anteriores, notadamente o Código de Napoleão (1804) e o Código Civil Alemão - BGB (1896), tutelava a família, então denominada de legítima, apenas se adviesse do sacramento matrimonial, incumbindo ao marido, chefe da sociedade conjugal,2 exercer os poderes gerenciais sobre todo o grupo familiar, então patriarcalista e patrimonializado.

O Código refletia, ao tempo de sua elaboração, a imagem da família patriarcal, entronizada num país essencialmente agrícola, com insignificantes deformações provenientes das disparidades da estratificação social. Sob permanente vigilância da Igreja, estendida às mais íntimas relações conjugais e ao comportamento religioso, funcionava como um grupo

\footnotetext{
${ }^{1}$ Por meio dos cânones sagrados, havia proibição às relações de concubinato que se formavam ao lado dos rituais de casamento, além de denominarem como ilegítimos os filhos nascidos fora do casamento e avançarem na evolução de regras sobre os impedimentos matrimoniais e relações de parentesco.
} 
altamente hierarquizado, no qual o chefe exercia os seus poderes sem qualquer objeção ou resistência, a tal extremo que se chegou a descrevê-la como um agregado social constituído por um marido déspota, uma mulher submissa e filhos aterrados (GOMES, 1984, p. 64).

Percebia-se, assim, que o Código Civil de 1916 dava ao casamento as características da indissolubilidade e eternidade, refletindo a máxima canonista "o que Deus uniu, o homem não separe". Isso demonstrava a grande influência que a religião exercia sobre o próprio Direito e sobre a estrutura familiar numa sociedade, que não recebia qualquer proteção se não se abrigasse no burocrático, ritualístico e sacramentado vínculo do casamento.

No período subsequente, especialmente após as Guerras Mundiais, houve grandes mudanças, fruto de uma crescente evolução social, cultural e econômica, que levaram à emancipação da mulher, que passou a ingressar no mercado de trabalho, ${ }^{3}$ ao crescimento industrial e ao fortalecimento do sistema capitalista, que também refletiu em alterações na estrutura familiar e formação de uniões de pessoas à margem do casamento.

Como bem salientado por Renata Barbosa de Almeida e Walsir Edson Rodrigues Júnior (2012, p. 91), in verbis:

Todavia, algumas estruturações que se engedravam na realidade mostravam-se indispostas a tal dogmática religiosa, dela, então, diferenciando-se. Sugeriam outras pretensões, outros propósitos, ainda que de maneira disforme. A constituição da família, para certo grupo, parecia dispensar a benção divina e também o próprio reconhecimento e amparo jurídicos. Eram as famílias informais, não oriundas do casamento, mas que de fato existiam.

Naquele período, surgiram os denominados direitos sociais que regeram o chamado Estado do Bem-estar Social, como um novo modelo político-estatal inspirado no valor da solidariedade, de modo a garantir aos cidadãos um mínimo de bens necessários à subsistência digna. Tudo isso refletiu no reconhecimento de diversos direitos sociais, dentre os quais o direito ao trabalho, à greve, à saúde, dentre outros.

A Constituição Federal de 1988, na tentativa de absorver pelo menos algumas dessas mudanças no meio social, diante dos novos modelos de família, cada vez mais aceitos e não mais vinculados ao casamento, sem características patriarcais ou patrimonialistas, dedicou todo um capítulo à instituição, denominando-a como a base da sociedade e merecendo uma especial proteção do Estado. ${ }^{4}$

\footnotetext{
${ }^{2}$ Art. 33. O marido é o chefe da sociedade conjugal, função que exerce com a colaboração da mulher, no interesse comum do casal e dos filhos. (Código Civil de 1916)
} 
Verificava-se, assim, no contexto do Estado Social, a intervenção não apenas nas relações jurídicas privadas de cunho patrimonial, mas também existencial, superando a velha concepção liberalista burguesa, "que entendia a família apenas como uma unidade política e econômica, comandada por um chefe patriarcal, e que, por se tratar de instituto eminentemente privado, não admitia a intervenção do poder político" (GURGEL, 2012, p. 41). Logo, como conclui a autora, a família passou a ser, constantemente, abrangida por normas de efeito protecionista. $^{5}$

Assistia-se, assim, ao fim daquele modelo unitário e transpessoal de família. Como bem salientado por Almeida e Rodrigues Júnior (2012, p. 91), in verbis: "definitivamente o casamento deixou de ser sinônimo de família e vice-versa. Diante da pluralidade reconhecida, ele passou a ser apenas uma das espécies familiares possíveis”.

O casamento, que, visto sob uma ótica institucionalista, era autônomo e intangível, passou a ser valorado de maneira instrumental, ou seja, funcionalizado, para que possa mediar e ser um núcleo intermediário de desenvolvimento da personalidade e realização da dignidade dos seus membros, sob a proteção do Direito de Família, que passou a ser interpretado segundo os valores constitucionais, a partir da repersonalização ${ }^{6}$ e da despatrimonialização do instituto da família. Vale dizer: o casamento deve servir às pessoas e não o contrário. O casamento é apenas um meio, ou seja, um instrumento para que as pessoas possam desenvolver a sua personalidade e buscar a sua felicidade e realização plena de vida.

Como consequência da "despatrimonialização" e "repersonalização", como valores inseridos no novo contexto da família, reinterpretada segundo os valores ditados pela Constituição da República de 1988, dentre os quais o fundamento da dignidade da pessoa humana (art. $1^{\circ}$, III) e objetivos da liberdade, solidariedade social (art. $3^{\circ}$, I) e igualdade substancial (art. $5^{\circ}$ ), valorizam-se a afetividade e a primazia da realização pessoal dos membros do grupo familiar, sem aquela preocupação exagerada que do sistema jurídico em relação ao patrimônio familiar.

\footnotetext{
${ }^{3}$ A Lei $\mathrm{n}^{\circ}$ 4.121, de 1962, denominada de Estatuto da Mulher Casada, veio a admitir que a mulher pudesse exercer atividade profissional, aceitar herança ou legado, tutela ou curatela, sem necessidade de autorização marital.

${ }^{4}$ Art. 226. A família, base da sociedade, tem especial proteção do Estado.

${ }^{5}$ Paulo Luiz Netto Lôbo, em artigo sobre o tema, ressaltou diversos traços da expansão protecionista do Estado sobre a instituição familiar: "A Constituição de 1988 expande a proteção do Estado à família, promovendo a mais profunda transformação que se tem notícia, entre as constituições mais recentes de outros países. Alguns aspectos merecem ser salientados: a) a proteção do Estado alcança qualquer entidade familiar, sem restrições, explícita ou implicitamente tutelada pela Constituição; b) a família, entendida como entidade, assume claramente a posição de sujeito de direitos e obrigações; c) os interesses das pessoas humanas, integrantes da família, recebem primazia sobre os interes ses patrimonializantes; d) a natureza socioafetiva da filiação prevalece sobre a origem exclusivamente biológica; e) consuma-se a igualdade entre os gêneros e entre os filhos; f) reafirma-se a liberdade de constituir, manter e extinguir entidade familiar e a liberdade de planejamento familiar, sem imposição estatal; g) a família configura-se no espaço de realização pessoal e da dignidade humana de seus membros." (2004, p. 143-144).
} 
Dessa forma, o vínculo afetivo passa a ser o elemento que distingue e identifica os novos laços familiares, gerando comprometimento mútuo, identidade de projetos de vida e propósitos comuns, sempre com fulcro em valores ligados ao próprio afeto, dentre os quais a confiança, a solidariedade, o respeito e a boa-fé.

O casamento, que pode ser definido, no contexto contemporâneo, como uma união entre pessoas que, "baseada na autonomia privada, instituem família por meio de um solene procedimento jurídico constitutivo, a partir do qual pretendem manter um elo conjugal estável e ostensivo, capaz de fomentar sua recíproca realização pessoal” (ALMEIDA; RODRIGUES JÚNIOR, 2012, p. 92), enquanto negócio jurídico sui generis, que se submete, em vários pontos, à teoria geral, inclusive no que se refere às invalidades, como será visto no tópico posterior, pode gerar efeitos jurídicos diversos, dentre os quais os relativos aos próprios cônjuges, aos filhos e, ainda, a terceiros que se relacionaram, por meio da confiança e da boa-fé, com os cônjuges em uma situação real ou aparente.

Nesse contexto pluralista da família e do casamento, como uma de suas espécies e assumindo uma função instrumentalizada no ordenamento jurídico contemporâneo, que também dá guarida a outros princípios e valores, dentre os quais o da confiança e da boa-fé, em suas duas acepções subjetiva e objetiva, é que se torna relevante e desafiador o estudo da teoria da aparência no campo do Direito de Família.

No presente trabalho, será, pois, analisado o instituto da teoria da aparência na ordem jurídica brasileira, com breves apontamentos sobre a sua origem, elementos e fundamentos, com a finalidade de demonstrar a sua aplicação no campo do Direito de Família, notadamente em relação ao instituto do denominado "casamento aparente" e sua necessária distinção dogmática do já conhecido casamento putativo. Por meio de revisão bibliográfica e jurisprudencial, pelo método dedutivo, visa-se contribuir, com algumas conclusões, para o enriquecimento do tema, que se há tornando relevante nos níveis acadêmico e prático.

\footnotetext{
${ }^{6}$ A respeito dos novos direitos fundamentais referentes às relações jurídicas de família, pode-se destacar a igualdade dos cônjuges em deveres e obrigações, o reconhecimento dos diversos formatos de família, não apenas da família formada pelo casamento, a igualdade entre os filhos, sejam eles nascidos ou não das justas núpcias.
} 


\section{O CASAMENTO PUTATIVO}

O casamento putativo é bem definido por Alípio Silveira (1972, p. 7), como "aquele nulo ou anulável, mas que, em atenção à boa-fé com que foi contraído por um ou ambos os cônjuges, produz, para o de boa-fé e os filhos, todos os efeitos civis até passar em julgado a sentença anulatória."

A nulidade de um casamento se refere a vício que se considere, por lei, ofensivo à ordem pública, em atenção ao próprio princípio da supremacia do interesse público. As hipóteses de nulidade do casamento são preceituadas no art. 1.548 do Código Civil, quais sejam: quando contraído o casamento por enfermo mental sem o necessário discernimento para os atos da vida civil ou quando contraído por infringência de impedimento. ${ }^{7}$

A decretação de nulidade do casamento pode dar-se via ação judicial, por iniciativa de qualquer interessado ou do Ministério Público, nos termos do art. 1.549 do mesmo Digesto Civil, sendo que não há prazo para se requerer a invalidação, por se tratar de ato jurídico nulo.

As hipóteses de anulabilidade, a seu turno, se referem a vícios de menor gravidade, por afrontarem interesses de ordem privada. De acordo com o art. 1.550 do Código Civil, é anulável o casamento: I - de quem não completou a idade mínima para casar; II - do menor em idade núbil, quando não autorizado por seu representante legal; III - por vício da vontade, nos termos dos arts. 1.556 a 1.558; IV - do incapaz de consentir ou manifestar, de modo inequívoco, o consentimento; $\mathrm{V}$ - realizado pelo mandatário, sem que ele ou o outro contraente soubesse da revogação do mandato, e não sobrevindo coabitação entre os cônjuges; VI - por incompetência da autoridade celebrante.

Ao contrário dos casos de nulidade, tratando-se de anulabilidade, há $\operatorname{prazos}^{8}$ diferentes

para que os legitimados exerçam seu direito em Juízo, de modo que haverá a convalidação do vício e, consequentemente, do casamento, em caso de silêncio ou inércia por parte do legitimado. Analisados os casos em que o legislador reputou o casamento passível de invalidade, em razão da nulidade ou anulabilidade, forçoso é concluir ser possível e, em muitos casos, admissível que um dos nubentes, ou ambos, esteja de boa-fé e tenha incorrido em erro escusável, o que caracterizará a putatividade do casamento

\footnotetext{
7 De acordo com o art. 1.521 do Código Civil, não podem casar: I - os ascendentes com os descendentes, seja o parentesco natural ou civil; II - o adotante com quem foi cônjuge do adotado e o adotado com quem o foi do adotante; III - os irmãos, unilaterais ou bilaterais, e demais colaterais, até o terceiro grau inclusive; IV - o adotado com o filho do adotante; V - o adotado com o filho do adotante; VI - as pessoas casadas; VII - o cônjuge sobrevivente com o condenado por homicídio ou tentativa de homicídio contra o seu consorte. Ainda, de acordo com o art. 1.522, os impedimentos podem ser opostos, até o momento da celebração do casamento, por qualquer pessoa capaz e, de acordo com o parágrafo único, devem ser opostos pelo juiz ou pelo oficial de registro, se tiverem conhecimento da sua existência.
} 
Yussef Said Cahali (1979, p. 4), em obra prestigiada sobre o casamento putativo, escrita sob a égide do Diploma Civil anterior, afirma, com propriedade, que a teoria que se forma em torno do casamento putativo fundamenta-se na proteção que parece necessária para assegurar a boa-fé dos nubentes, na medida em que eles (ou apenas um deles) acreditavam estar constituindo uma união honesta e válida.

E prossegue, in verbis: "a lei, para não conturbar profundamente a ordem familiar, constituída sobre a base da boa-fé, e para evitar os danos sociais da ilegitimidade da prole, faz a aparência valer como realidade; e converte em união legítima, a exterioridade material do vínculo, contornando-lhe o defeito".

O adjetivo putativo, segundo o dicionário Houaiss da língua portuguesa (2001, p. 2339), possui uma definição coloquial de ser aquilo "falsamente atribuído a alguém ou algo"; e também uma definição jurídica e oriunda "daquilo que, embora ilegítimo, é objeto de suposição de legitimidade, fundada na boa-fé”. A sua etimologia deriva do latim putativus, realçando a ideia de algo imaginário; e também do verbo putare, no sentido de acreditar e crer.

\footnotetext{
8 A anulação do casamento dos menores de dezesseis anos pode ser requerida pelo próprio cônjuge menor, por seus representantes legais e por seus ascendentes, no prazo de 180 (cento e oitenta) dias, contado do dia em que perfez dezesseis anos de idade, para o menor; e da data do casamento, para os seus representantes legais ou ascendentes (Código Civil, art. 1.555). O casamento do menor em idade núbil, quando não autorizado por seu representante le gal, só poderá ser anulado se a ação for proposta em 180 (cento e oitenta) dias, sendo legitimado o incapaz, ao deixar de sê-lo, bem como os seus representantes legais ou herdeiros necessários. De acordo com o art. 1.551, em qualquer dos dois casos, não se anulará, por motivo de idade, o casamento de que resultou gravidez.

Por outro lado, o prazo para ser ajuizada ação de anulação do casamento por erro essencial quanto a pessoa do outro cônjuge, conforme os arts. 1.556 e 1.557 do Código Civil, a contar do dia da celebração, é de 3 (três) anos e a legitimidade pertence apenas ao cônjuge que incidiu em erro ou que sofreu a coação, segundo o art. 1.559 e 1.560, III do Código Civil.

Já o prazo para se buscar a anulação do casamento, quando é realizado por procuração, apesar de já ter sido revogado o mandato, é de 180 (cento e oitenta) dias, a partir da data em que o mandante tiver conhecimento da celebração, caso não tenha instalado coabitação posterior, conforme o art. 1.550, V e 1.560, $\S 2^{\circ}$ do Código Civil. O outro cônjuge enganado também pode buscar o reconhecimento do vício, no mesmo prazo referido, a contar de quando teve ciência da revogação do mandato, ainda que tenha coabitado com o mandante.

E, por fim, o prazo para ser ajuizada ação de anulação do casamento, a contar da celebração, é de dois anos, em se tratando de celebração do casamento por autoridade incompetente em razão do lugar ou da pessoa, conforme o art. 1.550, VI e 1.560, II do Código Civil. Concordamos com o entendimento sufragado por Almeida e Rodrigues Júnior (2012, p. 145), no sentido de que "se se tratar de casamento celebrado por autoridade incompetente em razão da matéria, não há que se falar em anulabilidade e, sim, inexistência do casamento por falta de celebração".
} 


\subsection{ORIGEM HISTÓRICA E REGULAMENTAÇÃO DO CASAMENTO PUTATIVO NO DIREITO BRASILEIRO}

É controversa a origem do casamento putativo. Parte da doutrina entende que o casamento putativo surgiu no Direito Romano, enquanto outros doutrinadores asseveram que o instituto se originou no Direito Canônico e somente foi empregado pelos canonistas nos séculos XV e XVI.

Segundo Cahali (1979, p. 10), os textos que geralmente eram invocados e que induziram os doutrinadores à vinculação do casamento putativo ao Direito Romano dizem respeito, dentre outros casos, ${ }^{9}$ ao casamento celebrado por erro inter disparis conditionis personas (erroris causa probatio), que era uma forma de aquisição da cidadania romana provocada por um casamento putativo quanto à nacionalidade. Como exemplo, menciona o jurista o caso, extraído das Instituições de Gaio, de um casamento contraído por um cidadão romano com uma latina ou peregrina, acreditando que fosse cidadã romana (per ignorantiam, cum eam civem romanam esse crederet), mas que não o era, sendo, pois, despida do ius connubii. Nesse caso, se nascia algum filho de tal união, não tinha o pai sobre ele o então denominado pátrio poder, porque ele não era cidadão romano. Todavia, por um senatusconsulto, permitiu-se-lhe provar a causa do erro, oportunidade em que a mulher e o filho adquiriram a cidadania romana e se sujeitaram ao pátrio poder do homem e considerado chefe da família.

De qualquer forma, foi somente no Direito Canônico, nos séculos XI e XII, que surgiu uma teoria sistematizada a respeito do casamento putativo, através da qual, se um dos nubentes houvesse procedido de boa-fé, o matrimônio, embora nulo, produziria os mesmos efeitos de um casamento válido, no período anterior à decretação da nulidade, e também quanto aos filhos, já nascidos ou concebidos.

A razão do surgimento do casamento putativo está na máxima canônica "quod Deus coniunxit homo non separet", refletindo a sacralidade e a divindade do matrimônio religioso celebrado perante um padre e, pois, revestido de toda a proteção eclesiástica. Assim, como cresciam, naquela época, uniões ilegítimas, e surgiam pessoas de boa-fé que celebravam casamentos nulos, não poderia a Igreja, que ministrou o casamento, demonstrar sua fraqueza frente às invalidades do vínculo matrimonial contraído por pessoas de boa-fé, o que encontrou solução na criação e desenvolvimento do instituto do casamento putativo, como forma de

9 Outros textos podem ser invocados para vincular o casamento putativo ao Direito Romano, como o estabelecimento de pena na Constituição dos Imperadores Valentiano, Teodósio e Arcádio para os que "contra legum praecepta vel contra mandata constitutionesque Principum nuptias contraxerit" e, ainda, o rescrito dos Imperadores Marco e Lúcio a Flávia Tértula, pelo qual, em razão dos seus amplos poderes, concederam efeitos civis a um casamento celebrado com nulidade, porque já havia durado quarenta anos e do matrimônio foram concebidos inúmeros

filhos. 
proteger tais nubentes envolvidos na situação de invalidade do casamento, por meio da salvaguarda dos seus efeitos, desde que estivessem de boa-fé.

Com a criação do instituto pelos canonistas, o seu desenvolvimento científico se deu por sua aplicação nas Decretais dos Papas Alexandre III, Celestino III e Inocêncio III, nos séculos XII e XIII, que foram compiladas nas Decretais de Gregório IX, em 1230, juntamente com os Cânones do Concílio de Latrão e com as Decretais de Honório III. A partir das fontes legislativas do instituto, como salientado por Cahali (1979, p. 17), eram decididos inúmeros casos particulares, nos quais repetia-se o fundamento de que, ao ser declarado nulo o casamento contraído de boa-fé, ou seja, com a conviçcão de que se tratava de matrimônio válido, e desde que fosse celebrado publicamente (in facie Ecclesiae), os filhos dele nascidos deveriam ser considerados legítimos.

A partir do Direito Canônico, o instituto do casamento putativo foi assimilado por outros países do mundo ocidental, embora tenha havido uma diferença entre eles, o que levou Cahali (1979, p. 23) a subdivi-los em dois grupos, quais sejam: a) sistemas jurídicos que se aproximam do tratamento conferido pelo Direito Canônico e Comum, fazendo depender os efeitos jurídicos do casamento nulo ou anulável do fato de estar presente a boa-fé de pelo menos um dos cônjuges, quando da celebração do casamento, como ocorreu no Direito Francês, Italiano, Espanhol, Português, Argentino, Mexicano e Brasileiro; b) sistemas em que a boa-fé, seja unilateral ou bilateral dos cônjuges, não é fundamento para que haja um tratamento diferenciado quanto o casamento nulo ou anulável, que continua seguindo, em regra, o sistema geral de nulidades do sistema jurídico, como se observou no antigo Direito Prussiano e no Direito Suíço.

No mesmo sentido, ao tratar do primeiro grupo de países que acolheu o casamento putativo em seu sistema jurídico, com fundamento na boa-fé, veja-se o escólio de Alípio Silveira (1972, p. 8), in verbis:

\footnotetext{
A Revolução francesa instituiu o casamento civil, que foi propagado a outras nações. Mas os países de maioria católica, a começar pela França, acolheram igualmente o casamento putativo em sua lei civil, como sucedeu em Espanha, Portugal, Itália. O Código espanhol foi mais longe, pois seu artigo 69 dá como legítimos os filhos de casamento radicalmente nulo, contraído de má-fé por ambos os cônjuges.
}

No Brasil, como aponta Francisco Amaral (2008, p. 161), a evolução do Direito Civil pode ser dividida em três fases bem delimitadas: a que vai do descobrimento do Brasil à codificação; a que se refere ao processo de codificação, que culminou na edição do Código Civil de 1916 e aquela que se inicia em momento posterior ao Código até agora, na fase contemporânea em que se assistiu à edição do Código Civil de 2002. 
No início, na fase colonial brasileira, aplicava-se a legislação portuguesa referente às Ordenações Filipinas e era atribuído muito valor aos usos e costumes, como fonte de Direito. Em relação ao matrimônio, a Igreja ditava as regras que deviam ser observadas pelos nubentes, de modo que o Direito Canônico era a fonte do Direito Positivo a respeito do tema, aplicando-se as disposições do Concílio de Trento, sem qualquer intervenção do Estado.

Já na fase imperial, que teve como marco a abertura dos portos por Dom João VI, em 1808, o primeiro passo para a desvinculação do poderio eclesiástico sobre o casamento ocorreu com o Decreto $\mathrm{n}^{\mathrm{o}} 1.144$, de 11 de setembro de 1861, que regulou o casamento entre pessoas de seitas dissidentes, celebrado em harmonia com as prescrições de cada uma das religiões.

Em seguida, por força da determinação constante do art. 179 ( $n^{\circ}$ XVIII) da Constituição do Império, de 25 de março de 1824, no sentido de que fosse organizado um Código Civil fundado nas sólidas bases da justiça e da equidade foram realizados projetos de codificação por Teixeira de Freitas, ${ }^{10}$ Nabuco de Araújo, Joaquim Felício dos Santos ${ }^{11}$ e Antônio Coelho Rodrigues. $^{12}$

Finalmente, com a implantação da República, em 1889, em virtude da laicização do Estado, o instituto passou a ser regulado pelo Direito Comum, tendo havido a secularização do casamento, por meio do Decreto $\mathrm{n}^{\circ} 181$, de 24 de janeiro de 1890 , que continha regra expressa sobre o casamento putativo, in verbis:

\footnotetext{
“Art. 75. Quando o casamento nulo ou anulável tiver sido contraído de boa-fé, produzirá os seus efeitos civis, quer em relação aos cônjuges, quer em relação aos filhos, ainda que êstes fossem havidos antes do mesmo casamento. Todavia, se só um dos cônjuges o tiver contraído de boa-fé, o casamento só produzirá efeito em favor dêle e dos filhos.”
}

\begin{abstract}
No Esboço de Teixeira de Freitas, foi adotada, de forma bastante exaustiva, a regulamentação sobre o casamento putativo. Dispunha, no art. 1.447, que se o casamento anulado fosse contraído de boa-fé, produziria os mesmos efeitos civis de um casamento válido dissolvido; e, segundo o art. 1.448, se houve boa-fé de ambos os cônjuges, o casamento, até o dia da sentença, produz todos os efeitos do casamento válido, tanto em relação às pessoas e aos bens dos cônjuges, como em relação aos filhos. Ainda, de acordo com o art. 1.449, se apenas um dos cônjuges esteve de boa-fé, produzem-se também todos os efeitos do casamento válido, mas somente em relação a ele e aos filhos. O projeto dispunha, ainda, sobre direitos indenizatórios, ao dispor, no art. 1.452, in verbis: "o cônjuge de boa-fé poderá demandar ao cônjuge de má-fé, e contra terceiros que tenham provocado o êrro, pela indenização de todo dano que haja sofrido"; e, também, ao preceituar, no art. 1.453, in verbis: "em qualquer caso, a nulidade não prejudica direitos adquiridos por terceiros, que de boa-fé houverem contratado com os supostos cônjuges".

11 O projeto de Felício dos Santos, menos completo, estabelecia, no art. 676 e parágrafo, que qualquer casamento, ainda que anulado fosse, produziria efeitos civis, desde o dia da celebração, tanto em relação aos cônjuges, como a seus filhos, se contraído de boa-fé por ambos os cônjuges; ainda que, posteriormente, ambos ou apenas um deles estivesse de má-fé. De acordo, ainda, com o art. 677, se a boa-fé fosse unilateral, somente o cônjuge inocente e os filhos teriam proveito do casamento nulo ou anulado.

$12 \mathrm{O}$ projeto de Coelho Rodrigues, em seu art. 1.916, preceituava: "quando o casamento nulo ou anulável tiver sido contraído de boa-fé, produzirá os efeitos civis, quer em relação aos cônjuges, quer em relação aos filhos, ainda que havidos antes do mesmo". E dispunha, ainda, em seus parágrafos, "se só um dos cônjuges esteve de boa-fé, o casamento só produzirá efeito em favor dêle e dos filhos; neste caso, ainda que o regime tivesse sido de comunhão universal, o cônjuge inocente poderá, se esta prejudicá-lo, pedir a separação dos seus bens anteriores e da metade dos adquiridos pelo casal". No referido projeto, há uma verdadeira sanção legal ao cônjuge que agiu de má-fé, quando da celebração do casamento, como se nota na redação do art. 1.917, in verbis: "o cônjuge culpado perderá todas as vantagens havidas do outro ou por atenção a êle, e ficará, não obstante, obrigado a cumprir até as promessas não realizadas, que lhe houver feito no respectivo contrato antenupcial"'.
\end{abstract}


Yussef Said Cahali (1979, p. 42), menciona a observação de Macedo Soares, no sentido de que, a partir de então, foi consagrada a doutrina da putatividade do casamento na legislação dos povos cultos, seguindo, com pequena variação, a doutrina que já se encontrava nos códigos França, da Sicília, da Áustria, da Sardenha e da Baviera. Todavia, por não trazer solução sobre a situação dos filhos advindos da união denominada corporal adulterina ou incestuosa, continuava a haver controvérsia sobre o tema.

Anos depois, precisamente em 1899, não tendo havido a aprovação de nenhum dos projetos de codificação anteriores, encarregou-se Clóvis Beviláqua, a convite do então Ministro da Justiça Epitácio Pessoa, para prosseguir no trabalho de codificação, que já havia se iniciado nos anos anteriores, com a missão de aproveitar, no que fosse possível, as ideias já consagradas em tais documentos, tendo sido concluído em outubro de 1899. O novo projeto, após as discussões parlamentares, foi sancionado e promulgado com a Lei $n^{\circ} 3.071$, de $1^{\circ}$ de janeiro de 1916, e, pois, introduzido no direito brasileiro como o Código Civil de 1916.

Tal diploma foi um fruto da sua época e refletiu, no campo da família, o patriarcalismo doméstico que dominava a sociedade da época e também o absolutismo do pátrio poder exercido pelo marido, sem grandes preocupações com a filiação ilegítima, que ainda sofria grande preconceito social. No que se refere à putatividade do casamento, não houve grandes mudanças em relação ao regramento anteriormente inserido Decreto $n^{\circ} 181$, de 24 de janeiro de 1890, como se observa na regra expressa a respeito no capítulo referente ao casamento nulo e anulável, in verbis:

Art. 221. Embora nulo ou anulável, quando contraído de boa-fé por ambos os cônjuges, o casamento em relação a estes como aos filhos, produz efeitos civis desde a data da sua celebração.

Parágrafo único. Se um dos cônjuges estava de boa-fé, ao celebrar o casamento, os seus efeitos civis só a esse e aos filhos aproveitarão.

Instituída estava, assim, em um único artigo a fonte normativa do casamento putativo no Direito Civil brasileiro, que trouxe para o ordenamento jurídico nacional o que havia de mais evoluído e avançado sobre o tema no Direito estrangeiro, ainda que houvesse lacunas ${ }^{13}$ que seriam resolvidas pela jurisprudência e pela doutrina ao longo dos anos.

A própria legislação, no entanto, tratou de solucionar algumas controvérsias formadas, como ocorreu com a edição da Lei $\mathrm{n}^{\circ}$ 6.515, de 1977, que regulou o divórcio e trouxe importante proteção aos filhos, ainda que não houvesse boa-fé por parte de nenhum dos cônjuges. Veja-se:

Art. 14. No caso de anulação do casamento, havendo filhos comuns, observar-se-á o disposto nos arts. 10 e 13.

Parágrafo único. Ainda que nenhum dos cônjuges esteja de boa fé ao contrair o casamento, seus efeitos civis aproveitarão aos filhos comuns.

\footnotetext{
13 Uma das lacunas que sempre gerou controvérsias diz respeito à aplicação da putatividade, quando se tratasse de casamento inexistente, tendo em vista que não havia (como não há) regulamentação expressa a respeito do tema. Ademais, o art. 221 do Código Civil de 1916 somente tratou do casamento nulo ou anulável. 
Com tal regramento, todo casamento declarado nulo ou anulado passou a ser considerado como putativo com relação aos filhos, superando a antiga preocupação em se analisar e diferenciar a putatividade de acordo com os efeitos pessoais que advinham do casamento, iniciando-se, assim, um marco evolutivo no instituto que passou a ser direcionado no sentido de se dar mais valor apenas aos efeitos patrimoniais advindos da putatividade do casamento, o que refletia a evolução no campo do direito privado em direção à repersonalização e despatrimonialização das relações jurídicas.

\subsection{O CASAMENTO PUTATIVO NO CÓDIGO CIVIL DE 2002}

Com as mudanças sociais, econômicas e políticas que se verificaram ao longo do século XX, exigiu-se uma reformulação da anterior codificação civilista, que nasceu inspirada no liberalismo econômico e guardava preocupação excessiva com o individualismo e patrimonialismo, o que chocava com os novos valores da socialidade, solidariedade e dignidade da pessoa humana, que passaram a caracterizar as relações jurídicas, especialmente após a Carta Constitucional de 1988.

Após as tentativas de revisão do Código Civil de 1916, foi nomeada comissão de juristas para a elaboração de um novo diploma civil, coordenada por Miguel Reale e composta por inúmeros civilistas, dentre os quais José Carlos Moreira Alves, Agostinho de Arruda Alvim, Sylvio Marcondes, Ebert Vianna Chamoun, Clóvis do Couto e Silva e Torquato Castro, tendo sido apresentado o anteprojeto em 1972, cuja redação foi publicada no Diário do Congresso Nacional em 1984, por meio do Projeto de Lei nº 634-B/75, que sofreu inúmeras atualizações e revisões, até que fosse publicada, em 11 de janeiro de 2002, a Lei no 10.406 , que continha o novo Código Civil Brasileiro.

O Código Civil de 2002, a exemplo do anterior, somente dispõe de um único dispositivo para regulamentar o instituto do casamento putativo, que se encontra inserido no capítulo referente à invalidade do casamento, in verbis:

\footnotetext{
Art. 1.561. Embora anulável ou mesmo nulo, se contraído de boa-fé por ambos os cônjuges, o casamento, em relação a estes como aos filhos, produz todos os efeitos até o dia da sentença anulatória.

$\S 1$ 1o Se um dos cônjuges estava de boa-fé ao celebrar o casamento, os seus efeitos civis só a ele e aos filhos aproveitarão.

$\S 2$ o Se ambos os cônjuges estavam de má-fé ao celebrar o casamento, os seus efeitos civis só aos filhos aproveitarão.
}

Como já verificado anteriormente, o sistema de nulidades em matéria matrimonial guarda especificidades em relação ao sistema geral de nulidades dos negócios jurídicos tratada na 
parte geral do Código Civil. Como bem mencionado por Sílvio de Salvo Venosa (2003, p. 137), "se obedecidos exclusivamente os princípios ordinários em matéria de nulidade, uma vez declarado nulo o casamento, o ato deixaria de produzir efeitos, cessando os que eventualmente tivessem sido produzidos". E, assim, o casamento seria considerando como uma mera união de fato, desapareceriam os efeitos advindos de tal entrelaço inválido, ainda que tivesse havido considerável transcurso de tempo, em claro prejuízo aos nubentes, aos filhos e a terceiros.

Todavia, desde os tempos dos canonistas, o legislador procura proteger todos os envolvidos na relação jurídica matrimonial inválida, em razão da proteção aos valores da boa-fé e da confiança que se fizeram inserir no núcleo do casamento, ainda que nulo ou anulado, em benefício da família, da prole e de terceiros, o que é sedimentado, há séculos, por meio do instituto do casamento putativo, no qual, como salienta Maria Helena Diniz (2013, p. 303), "a boa-fé suprime o impedimento, fazendo desaparecer a causa de sua nulidade por desconhecê-la".

É o caso de um irmão que se casa com a própria irmã, sem saber que era sua parente colateral e, somente em período posterior ao casamento, descobrem ambos a respeito do parentesco, tendo em vista que o pai biológico mantinha duas famílias sem que os familiares soubessem uma da outra. Um outro exemplo, seria o de um homem que se case com um outro homem ou com uma outra mulher já casada, o que reflete a existência da boa-fé apenas daquele.

Os requisitos para o reconhecimento da putatividade do casamento, segundo Cristiano Chaves de Farias e Nelson Rosenlvald (2014, p. 249), são: a) a invalidade do casamento; b) a boa-fé dos nubentes ou apenas de um deles; c) o erro desculpável; d) a declaração judicial.

A respeito da boa-fé para caracterizar a putatividade do casamento, Alípio Silveira (1972, p. 27) menciona, com propriedade, que há duas correntes a respeito. A primeira delas adere à concepção ética de boa-fé, que se refere, de forma positiva, à convicção legal ou crença positiva que os esposos tiveram, erradamente, de terem contraído casamento válido. A segunda corrente se refere ao denominado conceito psicológico de boa-fé e se traduz, de forma negativa, na mera ignorância, por parte dos esposos, do impedimento que obstava a realização da união matrimonial ou do vício que inquinava a sua celebração.

De qualquer forma, a ignorância, por parte dos esposos, do impedimento que obstava a realização da união matrimonial ou do vício que inquinava a sua celebração, na maioria dos casos, advém de um erro de fato, como no caso de um sogro que se case com a nora, sem ter conhecimento do vínculo de parentesco por afinidade.

Muito se discutiu, na doutrina, nacional e estrangeira, no entanto, se o erro que caracteriza a putatividade do casamento deveria ser ou não escusável (desculpável).

No Direito português há disposição expressa exigindo a escusabilidade do erro no casamento putativo, como se nota no art. $1.648^{\circ}$, n. ${ }^{\circ} 1$, in verbis: "Considera-se de boa fé o cônjuge que tiver contraído o casamento na ignorância desculpável do vício causador da nulidade 
ou anulabilidade, ou cuja declaração de vontade tenha sido extorquida por coacção física ou moral."

Em análise a tal dispositivo, Eduardo dos Santos (1999, p. 270), esclarece que, em tal presunção legal preceituada pelo Direito português, encontram-se ambos os sentidos da boa-fé: "ignorância desculpável do vício (sentido subjectivo e psicológico) e declaração de vontade que tenha sido extorquida por coacção física ou moral (sentido objectivo e ético)."

Da mesma forma, no Direito argentino, há exigência expressa sobre a escusabilidade do erro. Sobre o tema, veja-se o escólio dos juristas Pires de Lima e Borges da Cruz (1949, p. 280282), in verbis:

\begin{abstract}
O erro culposo não justifica a aplicação dos benefícios do casamento putativo. A orientação contrária parte do conceito subjetivo da boa-fé; admite que a boa-fé é o desconhecimento do vício, e daí conclui que, sempre que ele é desconhecido, com culpa do enganado ou sem ela, a boa-fé existe. Tal doutrina é inadmissível - não é o conceito subjetivo da boa-fé aquele que a nossa lei adota. Em resumo: só o erro desculpável é fundamento da boa-fé porque, no nosso direito, a boa-fé começa onde acaba a culpa
\end{abstract}

Em outras legislações, como na brasileira, francesa e italiana, há omissão legislativa sobre a escusabilidade do erro para que seja caracterizado o casamento putativo, o que sempre foi foco de grandes controvérsias a respeito do tema, especialmente no Direito brasileiro.

Carvalho Santos (1937, p. 257), em sua obra interpretativa sobre o Código Civil de 1916, já asseverava ser dispensável o erro escusável para que fosse qualificada a boa-fé como requisito para a putatividade do casamento. ${ }^{14}$ Veja-se:

\footnotetext{
Não é necessário, por outro lado, para que exista a boa-fé, que o êrro sôbre qual ela repousa seja escusável, como se queria no antigo direito. O que há é que os tribunais encarregados de apreciar a boa-fé poderão ter em consideração as diferentes circunstâncias suscetíveis de explicar e escusar a ignorância dos cônjuges; mas, em definitivo, a única questão que cabe aos tribunais decidir é a de fixar se há ou não boafé”.
}

Por outro lado, Moreira Guimarães (1953, p. 22) afirma que a boa-fé deve estribar-se no erro escusável, não bastando a simples convicção. ${ }^{15}$ Segundo o jurista, a aparência que produz efeitos jurídicos não é a que se constitui imaginosamente, mas a que se ordena por fatos sensíveis ou motivos ponderáveis.

Entendemos, todavia, com base no princípio da dignidade da pessoa humana $\left(\mathrm{CF}\right.$, art. $1^{\circ}$, III) e também com fulcro nos valores da solidariedade social $\left(\mathrm{CF}\right.$, art. $\left.3^{\circ}, \mathrm{I}\right)$ e da igualdade $(\mathrm{CF}$,

\footnotetext{
${ }^{14}$ No mesmo sentido, Eduardo Espínola (1922, p. 445).

15 Também no sentido de se exigir a escusabilidade do erro para a qualificação da boa-fé como requisito da putatividade do casamento, vejam-se Sílvio Rodrigues (1962, p. 110) e Washington de Barros Monteiro (1958, p. 198).
} 
art. $5^{\circ}$, caput), que ambas as acepções da boa-fé devem estar presentes para que seja caracterizada a putatividade do casamento, em relação aos nubentes, uma vez que deve sempre ser provada, não apenas uma mera ignorância sobre o impedimento matrimonial ou vício que inquinava a

celebração do casamento, mas também a diligência do interessado em ter se portado com retidão,honestidade e ética em relação ao matrimônio contraído ${ }^{16}$, o que deve ser analisado no caso concreto, por parte do magistrado.

Por conseguinte, devendo haver as duas acepções da boa-fé, analisadas no caso concreto, pelo magistrado, a escusabilidade do erro já fará parte de uma convicção legal ou crença positiva que os esposos tiveram, erradamente, de que contraíam um casamento válido, quando, na realidade, não estavam, motivo pelo qual, em que pese a necessidade de estar presente a existência de um erro para a configuração da putatividade do casamento, nem sempre deverá ser exigida a sua escusabilidade para que seja caracterizada a boa-fé, em suas duas acepções, no caso concreto.

Rodolfo Sacco, mencionado por Alípio Silveira (1972, pp. 37-38), em importante estudo sobre o tema, corroborando o entendimento acima, afastou a exigência da escusabilidade do erro como requisito necessário para o reconhecimento da putatividade do casamento. ${ }^{17}$ Veja-se:

\footnotetext{
Uma parte da tradição canonista exigia, aliás, a escusabilidade do êrro; o B.G.B. (hoje abrogado na parte relativa ao casamento) não protegia o êrro culposo, mas os códigos francês, espanhol, canônico, italianos de 1865 e 1942, deixam em pé a questão. O recurso à analogia não é permitido em razão das incertezas e da variedade da ratio juris que preside às várias normas. Os elementos histórico, teleológico e comparativo não dão indicações seguras.

Talvez não reste outra solução senão admitir em princípio, a suficiência da boa-fé medida in concreto, temperando (em nome dos princípios gerais do direito) êste critério nos casos marginalíssimos, nos quais o que erra é absolutamente idigno de tutela (casos que, evidentemente, não se podem catalogar de modo típico).
}

16 AÇÃO DE ANULAÇÃO DE CASAMENTO - CONTRAENTES SEPARADOS JUDICIALMENTE IMPEDIMENTO - INTELIGÊNCIA DO ART. 183, VI, DO CÓDIGO CIVIL - BOA- FÉ - INOCORRÊNCIA PRODUÇÃO DOS EFEITOS CIVIS AFASTADA. Os separados judicialmente não podem convolar novas núpcias, as quais serão declaradas nulas, nos termos do art. 183, VI, do Código Civil. Embora a boa-fé dos consortes seja presumida, havendo prova nos autos de que tinham eles ciência do impedimento existente, não se apresenta possível proclamar a putatividade do matrimônio. Sentença mantida em reexame necessário. (MINAS GERAIS, 2001)

17 Yussef Said Cahali (1979, p. 85) também manifesta o mesmo entendimento do jurista italiano e ainda complementa, in verbis: "Exigir, como regra geral, que o êrro seja escusável, isto é, exigir em definitivo aquela diligência, abstrata ou concretamente considerada, significa, em muitos casos, excluir o próprio conceito de boa-fé, deixando, em consequência, à margem da proteção, situações tais que, justamente pela absoluta ignorância ou errada convicção do sujeito, não houve diligência alguma de sua parte. Assim, a escusatória do êrro não se fixa bem como elemento a priori de qualificação do casamento putativo, melhor se resolvendo como elemento de apreciação de fato da boa-fé". 
No que se refere ao erro de direito, foi expressamente contemplado no inciso III do art. 139 do Código Civil Brasileiro e tem sido admitido para caracterizar o casamento putativo, devendo, entretanto, ser analisado, caso a caso, se a intenção dos nubentes (ou de um deles) era simplesmente de se furtar à incidência legal, sob a alegação de desconhecimento, o que é vedado pelo referido dispositivo, ou se houve efetivamente a boa-fé qualificadora do erro em questão.

Em interessante julgado, o Tribunal de Justiça do Estado de São Paulo confirmou a sentença proferida pelo julgador a quo, que reconheceu a incidência do erro de direito qualificado pela boa-fé de ambos os nubentes para caracterizar a putatividade de um casamento nulo celebrado, em razão de ter sido realizado sem a posterior conversão em divórcio da separação anterior de um dos nubentes. Colaciona-se, abaixo, a ementa do acórdão, in verbis:

Casamento - Nulidade - Casamento putativo - Boa-fé de ambos os nubentes Separação consensual do carão, sem que houvesse posterior conversão da separação em divórcio - Bigamia - Nulidade do segundo casamento caracterizada - Sentença correta (SÃO PAULO, 1998)

Por sua vez, o momento em que se reclama a boa-fé para os efeitos da putatividade deve ser o da celebração do casamento, ainda que se tenha descoberto o vício em momento posterior. Assim, se o adotado se casa com um outro filho do adotante, sem que tivesse ciência do parentesco e, ao saber, continue com ele casado, futuro reconhecimento de anulação do casamento com os efeitos da putatividade deverá ser decretada em respeito à boa-fé daquele cônjuge que desconhecia o impedimento que deu causa à declaração de nulidade (Código Civil, art. $1.521, \mathrm{~V}$ c/c 1.548, II).

Finalmente, para que haja o casamento putativo é necessário que a invalidade do casamento seja reconhecida na própria sentença que declare nulo o casamento ou que o desconstitua $^{18}$ ou em demanda autônoma declaratória de putatividade, promovida a qualquer tempo pelo interessado. E, como bem salientado por Cristiano Chaves de Farais e Nelson Rosenvald (2014, p. 250), admite-se o reconhecimento ex officio da putatividade, na própria sentença da ação declaratória de nulidade ou anulatória, porquanto a produção dos seus efeitos decorre de um comando legal, fundado na boa-fé e, assim, independe de formulação expressa de pedido pela parte. ${ }^{19}$

\footnotetext{
18 Adverte, no entanto, Maria Berenice Dias (2007, p. 263) que a busca de declaração de nulidade do casamento pode ocorrer a qualquer tempo, porque a ação é imprescritível e não sujeita a prazo decadencial; ao contrário do casamento anulável, que só pode ser desconstituído se a demanda for proposta dentro de determinados prazos, que variam de conformidade com o vício nulificante, de acordo com o art. 1.560 do Código Civil. Ainda segundo a jurista, apesar de a lei falar em prescrição, no caso do casamento anulável, na verdade o prazo para se buscar a anulação do matrimônio é decadencial, em razão da natureza da ação.

19 Em sentido contrário, Sílvio de Salvo Venosa (2003, p. 144) entende que o pedido de putatividade deve ser expresso e incluído na pretensão anulatória, ainda que feito no curso da ação, sem que se modifique o anterior pedido ou causa de pedir, se o permitir o estágio probatório do processo.
} 


\subsection{EFEITOS DA PUTATIVIDADE DO CASAMENTO}

Embora nulo ou anulado, em respeito à boa-fé de ambos ou de um dos cônjuges, o casamento em relação a eles e aos filhos, de acordo com o art. 1.561 do Código Civil, produz todos os efeitos de um casamento válido até a data da sentença anulatória, a qual terá eficácia ex nunc, ao contrário do sistema geral de nulidades da lei civil que, equivocadamente, determina seja a eficácia ex tunc em casos de nulidade. Equivocadamente, porque o que mais há são exemplos de nulidade, cuja sentença produz efeitos ex nunc. Dentre eles, pode-se citar o próprio casamento putativo.

Assim, os cônjuges (ou apenas um deles) que estiverem de boa-fé podem invocar em seu favor todos os efeitos de um casamento válido, dentre os quais a validade do pacto antenupcial, a comunhão dos bens e, inclusive, o direito de sucessão. Todavia, como bem salientado por Almeida e Rodrigues Júnior (2012, p. 146), não lhes é lícito tomar o casamento como válido numa parte e nulo noutra, escolhendo valerem-se apenas de alguns efeitos.

E, naturalmente, o direito de suceder ${ }^{20}$ em relação ao cônjuge de boa-fé somente ocorrerá se a morte do outro cônjuge se verificar até a data da sentença anulatória; uma vez que, a partir de então, o casamento terá deixado de existir no mundo jurídico e os cônjuges perderão tal qualidade e, consequentemente, deixarão de ser herdeiros um do outro.

O cônjuge de má-fé, a seu turno, fica privado retroativamente da qualidade de esposo e perde as vantagens econômicas advindas do casamento: não poderá ser considerado herdeiro do outro e nem poderá pretender a meação do outro cônjuge, o que, aliás, restou expressamente preceituado como regra geral no art. 1.564 do Código Civil. ${ }^{21}$

Todavia, Sílvio de Salvo Venosa (2003, p. 142) adverte que serão partilhados "normalmente os bens adquiridos pelo esforço comum, como regra de equidade, independentemente da natureza do desfazimento do casamento, sob pena de enriquecimento ilícito de um dos cônjuges às custas do outro, o que é vedado por nosso ordenamento jurídico".

Por outro lado, o cônjuge emancipado que tiver contraído o casamento de má-fé, especialmente se o fez apenas para obter a plena capacidade civil, perderá a emancipação. Situação diversa, no entanto, ocorrerá se tiver sido reconhecida judicialmente a sua boa-fé, quando da anulação do casamento, porquanto continuará emancipado.

Questão controvertida se refere ao dever de prestar alimentos como um dos efeitos da putatividade do casamento. Sobre o tema, formaram-se duas correntes. A primeira entende que não haja qualquer limitação de tempo para o dever de prestar alimentos ao cônjuge de boa-fé na putatividade do casamento reconhecido na sentença anulatória. Sobre o tema, transcreve-se, abaixo, a ementa de aresto do Tribunal de Justiça do Estado do Paraná, in verbis: 
Ação de alimentos - Anulação de casamento - Bigamia - Boa-fé do cônjuge - Efeitos civis do casamento putativo. Art. 221 e seu parágrafo do Código Civil. Ação procedente

- Recurso improvido. A putatividade, no casamento anulável ou mesmo nulo, consiste em assegurar ao cônjuge de boa-fé os efeitos do casamento válido, entre os quais encontra-se o direito a alimentos, sem limitação no tempo (PARANÁ, 1994).

Almeida e Rodrigues Jr. (2012, p. 147) manifestam o entendimento sobre a possibilidade de permanência da obrigação alimentar, em situações excepcionais, em favor do cônjuge de boafé mesmo após a anulação do casamento, em razão de a putatividade visar a assegurar os efeitos de um casamento válido para quem realizou o casamento de boa-fé. Como exemplo, os juristas descrevem a hipótese de um cônjuge de boa-fé que foi dona de casa, com a concordância do marido, durante todo o período do casamento anulado e sem qualquer fonte de renda para se manter. Nesse caso, não se poderia simplesmente fazer cessar o dever de prestar alimentos com a sentença anulatória.

A segunda corrente, corroborada pelo Superior Tribunal de Justiça, defende que, reconhecido o casamento putativo, os alimentos são devidos ao cônjuge de boa-fé e necessitado apenas até a data da sentença anulatória do casamento. Veja-se:

Casamento putativo. Boa-fé. Direito a alimentos. Reclamação da mulher.

1. Ao cônjuge de boa-fé aproveitam os efeitos civis do casamento, embora anulável ou mesmo nulo (Cód. Civil, art. 221, parágrafo único).

2. A mulher que reclama alimentos a eles tem direito mas até à data da sentença (Cód. Civil, art. 221, parte final). Anulado ou declarado nulo o casamento, desaparece a condição de cônjuges.

3. Direito a alimentos "até ao dia da sentença anulatória".

4. Recurso especial conhecido pelas alíneas a e c e provido (BRASIL, 2000)

20 Questão controvertida se refere ao casamento putativo do bígamo, uma vez que, declarada a putatividade do casamento, e morrendo ele, poderá haver o conflito entre os dois cônjuges como herdeiros (logicamente se for reconhecida a boa-fé do cônjuge na sentença anulatória do segundo casamento). Nesse caso, como mencionado por Yussef Said Cahali (1979, p. 139), a maioria da doutrina entende que a herança deverá ser dividida em partes iguais entre o cônjuge legítimo e o putativo.

21 Cristiano Chaves de Farias e Nelson Rosenvald (2014, p. 250) criticam a perda de vantagens com base na assunção de culpa a ser reconhecida judicialmente, in verbis: "Em atitude posidiconada na contramão da evolução da ciência jurídica (e das ciências humanas como um todo), o legislador insiste em punir o culpado pela anulação do casamento. Afirma, então, o art. 1.564: quando o casamento for anulado por culpa de um dos cônjuges, este incorrerá: I - na perda de todas as vantagens havidas do cônjuge inocente; II - na obrigação de cumprir as promessas que fez no contrato anteupcial. Da maneira com que se redigiu esse péssimo dispositivo, parece que o casamento é uma troca de vantagens patrimoniais, que podem ser perdidas por conta de uma eventual culpa (se é que algum jurista teria condições, em todos os sentidos, de reconhecer quem foi o culpado e quem foi o inocente, afinal como bem disse, generosamente, CHICO BUARQUE DE HOLANDA, te perdoo, por te trair). 
Quanto aos filhos, é irrelevante a perquirição da boa-fé dos cônjuges, uma vez que a anulação do casamento não prejudicará a sua condição de legítimos, em respeito ao próprio $\S 2^{\circ}$ do art. 1.561, sendo vedada e inadmissível qualquer discriminação em relação a eles, aliás, como veda a própria Constituição da República, no art. $227, \S 6^{\circ}$, in verbis: "os filhos, havidos ou não da relação do casamento, ou por adoção, terão os mesmos direitos e qualificações, proibidas quaisquer designações discriminatórias relativas à filiação".

Superada a análise sobre a origem histórica, requisitos e efeitos do casamento putativo no direito brasileiro, a seguir, serão feitos breves apontamentos sobre a teoria da aparência e o seu reconhecimento pelo direito pátrio para, posteriormente, ser identificado o instituto do casamento aparente e a sua necessária distinção em relação ao casamento putativo.

\section{BREVES APONTAMENTOS SOBRE A TEORIA DA APARÊNCIA}

Na vida cotidiana são realizadas inúmeras relações intersubjetivas, celebrando contratos, estabelecendo vínculos de natureza patrimonial e existencial, ou seja, criando, modificando, extinguindo e implementando diversos atos que são de grande importância para o mundo jurídico.Em tais relações intersubjetivas, haverá, algumas vezes, situações fáticas que não correspondem à mesma situação jurídica, embora possam se revestir como tal, o que leva ao aparente conflito entre a enganosa visualização da exterioridade e a legítima correspondência real, ou seja, um vislumbrado antagonismo entre a expectativa de direito de um terceiro de boa-fé e a própria legitimidade do titular do direito.

A aparente contradição é objeto de crescente preocupação para os estudiosos do Direito, passando a ser rotulada como teoria da aparência a invocação levada a efeito pelos juristas para aclamar a solução conferida aos conflitos que derivam dos seus fatos ensejadores.

A denominada teoria da aparência ou aparência de direito, apesar de não contar com estudos doutrinários mais profundos, tem sido fonte de diversos absurdos perpetrados pelos julgadores em demandas judiciais, bem como fruto de acirradas polêmicas entre os juristas.

Segundo o Pequeno Dicionário da Língua Portuguesa (FERREIRA, 1972), o significado da palavra aparência é: "aquilo que se mostra à primeira vista; aspecto; exterioridade; aquilo que parece e não é realidade; mostra enganosa, fingimento; disfarce". A aparência substitui a realidade em favor de quem agiu com boa-fé. Na situação aparente, há uma relação real para esse terceiro, mas, que na verdade, não encontra veracidade jurídica.

A aparência de direito pode ser conceituada como "uma situação de fato que manifesta como verdadeira uma situação jurídica não verdadeira, e que, por causa do erro escusável de 
quem, de boa-fé, tomou o fenômeno real como manifestação de uma situação jurídica verdadeira, cria um direito subjetivo novo, mesmo à custa da própria realidade.” (Malheiros, 1978, p. 46).

Assim, com base em tal definição, haveria um aspecto interior, que revela uma realidade interior e imaginada pelo agente e, por outro lado, uma manifestação exterior daquela realidade, a qual, poderá ser falsa (não titular do direito) ou verdadeira (titular do direito).

A legislação pátria reproduziu em seu corpo $^{22}$ diversas hipóteses de aplicação da teoria geral da aparência, dentre as quais o instituto do casamento aparente, que será analisado a seguir, a despeito de ser assente na doutrina o fato de que se furtou o próprio legislador de capitular os diversos casos em que o princípio poderia ser aclamado.

Todavia, nos casos não tratados expressamente pelo ordenamento jurídico, mas que demandem proteção a terceiros de boa-fé que se relacionem, por erro invencível, com aparentes titulares, deve o Direito proteger a situação evidenciada, sob a proteção do erigido princípio geral da aparência, abalizador dos valores estruturadores da equidade e da confiança entre os indivíduos, ainda que a salvaguarda levada a efeito se posicione contra o direito do verdadeiro e legitimado titular, mas, sempre, observados os requisitos próprios para a aplicação do princípio.

Assim, mesmo que a teoria da aparência ainda esteja em fase de desenvolvimento, e embora seja reconhecida pela doutrina e jurisprudência pátrias, inclusive sendo objeto de ricos trabalhos acadêmicos, ${ }^{23}$ ainda carece o instituto de mais esclarecimentos e aprofundamentos, de modo que seja reconhecida a sua legitimidade e eficácia, enquanto princípio jurídico ou aplicação direta e/ou analógica das regras existentes no ordenamento jurídico brasileiro, sempre tendo em vista os pilares da própria estrutura do Direito, amparada nos valores da boa-fé e equidade, como ideais de justiça (Chavinho, 2014, p. 14).

Embora ainda não tenha sido formulada uma teoria global sobre a estrutura da aparência de direito, como, aliás, mencionado por Orlando Gomes (1967), a doutrina costuma apontar três escolas, ao longo dos séculos anteriores, que procuraram sistematizá-la, quais sejam: a alemã, ${ }^{24}$ a francesa $^{25}$ e a italiana. ${ }^{26}$

${ }^{22}$ O Código Civil Brasileiro traz inúmeras referências à teoria da aparência, como se pode verificar nos casos de posse considerada como aparência da propriedade (art. 1.211), o herdeiro aparente (art. 1.817), dentre outros.(BRASIL, 2002). 
Encontra-se, porém, na época do "Corpus Iuris Civilis" uma famosa ocorrência ligada à teoria da aparência. Trata-se do episódio conhecido como Lex Barbarius, mencionado por Ulpiano no Liber 8 ad Sabinum, texto reproduzido no Digesto I, 14, 3, pelo qual o escravo Barbarius Philippus ter-se-ia passado por homem livre, tendo exercido, por muito tempo, o cargo de pretor, que jamais poder-lhe-ia caber. Posteriormente, o fato foi descoberto e houve sérios questionamentos sobre os atos praticados pelo escravo, então pretor, naquele período. Foi reconhecido que deveria prevalecer a validade dos atos praticados, em benefício dos terceiros de

boa-fé, por ter sido mais condizente com o espírito humanitário. O nome do escravo foi, então, perpetrado na história do Direito.

A aparência de direito, amparada nos valores da boa-fé e da confiança nas relações jurídicas, apresenta grande relevância no cenário jurídico por proteger os direitos da pessoa envolvida em uma situação fática aparente que não correspondente à realidade jurídica, e, justamente por incidir em um erro escusável e qualificado pela boa-fé, em suas duas acepções, realiza um negócio jurídico, que certamente não realizaria o negócio, caso tivesse ciência da real situação fática que lhe fora apresentada.

\footnotetext{
${ }^{23}$ Convém lembrar a obra de Fábio Maria De-Mattia: Aparência de representação. São Paulo: Rumo, 1984.

${ }^{24}$ A escola alemã tratou a teoria da aparência como um princípio geral da publicidade. Encontram-se, na doutrina alemã, duas regras básicas em termos de aparência: a primeira preceitua que a declaração negocial é eficaz, ainda que não corresponda à vontade da pessoa, se o destinatário daquela não sabia ou não tinha como saber que a declaração não era verdadeira. A segunda consiste em um ato de disposição de quem não é titular do direito de que dispõe, e tal ato será eficaz se resulta de indícios de "publicidade", salvo se o terceiro conhecia ou devia conhecer a realidade da situação. Nesse caso, salienta o jurista, seria o registro que daria a "aparência" de titularidade do bem. 25 A teoria da aparência, no direito francês, foi derivada da máxima do "error communis facit ius". O jurista Mazeaud (1924), em análise ao instituto no direito francês, observou que a aplicação inicial da teoria da aparência se referiu a uma norma de ordem pública, que formava um movimento que defendia a necessidade de ser sacrificado o interesse individual em favor do interesse social. A boa-fé coletiva deveria ser preponderante sobre o direito particular (titular do direito, em que foi observado o erro comum). Daí porque o erro comum, ou seja, aquele em que a massa incorreria, em qualquer circunstância, deveria ser prestigiado pelo Direito, ao ponto de ser afastada uma situação de direito, em benefício de uma situação de fato aparente, sempre visando o bem coletivo. Porém, o adágio do "error communis facit ius" foi, posteriormente, substituído pelo vício do ato ou negócio jurídico, como observado por Hélio Borgui (1999, p. 25). De qualquer forma, no sistema jurídico francês sempre foram prestigidados os brocardos "nemo plus iuris ad alium transferre potest quam ipse habet" ou "nemo dat quod non habet", ambos oriundos do Direito Romano, que fornecem proteção ao verdadeiro titular, tendo em vista que ninguém pode transferir um direito que não seja seu.

${ }^{26} \mathrm{Na}$ doutrina italiana, a teoria da aparência merece aplicação, desde que seja caracterizada, no caso concreto, a boafé do terceiro. Nos dizeres de Hélio Borgui, in verbis: "Assim, para a doutrina italiana, por exemplo, a transferência da pretensão à propriedade por quem não tem o direito de fazê-lo só leva à aquisição por quem está de boa-fé, quando houver por parte daquele ao menos a posse mediata da coisa a ser entregue, tendo sempre, pois, em função do direito positivo, certo poder de fato, ainda que esmaecido, de forma que na relação causal entre o pretendente e o possuidor haja se constituído um embasamento objetivo para a aplicação da teoria da aparência. Nos casos, porém, em que o cedente não se tornou possuidor mediato, o adquirente só se torna proprietário quando sobrevém a obtenção da posse, ou seja, através de circunstâncias que, de sua parte, justificariam objetivamente a aparência de direito, já que a circunstância de não só lhe ter sido cedida a pretensão à propriedade, mas também de o terceiro possuidor em consequência disso ter restituído (voluntária ou compulsoriamente) a coisa, confere à aparência de direitos uma suficiente base objetiva em favor do cessionário.” (BORGUI, 1999, p. 31).
} 
Vicente Ráo (1978, p. 243), ao tratar do fundamento da aparência de direito, bem apresentou o seu fundamento como a necessidade de a ordem social conferir segurança às operações jurídicas, amparando-se, ao mesmo tempo, os interesses legítimos dos que corretamente procedem.

Como bem salientado por Arnaldo Rizzardo (1982), in verbis:

\begin{abstract}
A rapidez e a segurança do comércio, a quantidade de negócios comuns que se impõem diariamente, os compromissos que se avolumam constantemente, o condicionamento da vida a uma dependência de relações contratuais inevitável, entre outros fatores, formam as causas que levam o homem a não dar tanta importância ao conteúdo dos atos que realiza, prendendo-o ao aspecto exterior dos eventos que se apresentam
\end{abstract}

Nos dias atuais, em que não precisamos mais celebrar negócios jurídicos de modo presencial e sem que conheçamos a pessoa do outro contratante, faz com que haja uma maior proteção, por parte do ordenamento jurídico, à boa-fé e à confiança, para que haja o maior desenvolvimento do comércio e das relações jurídicas em geral.

As necessidades sociais, cada vez mais, exigem que o formalismo na exagerada cautela em se verificarem aspectos íntimos das partes contratantes não deva ser mais promovido no mundo, sob pena de causar um enorme empecilho ao comércio e às relações existentes entre as pessoas.

A presunção de que exista a honestidade e a confiança esperada em cada relação jurídica deve ser interpretada de modo a que o Direito possa salvaguardar a legítima expectativa do terceiro de boa-fé, o seu direito deve ser reconhecido, porquanto ele, terceiro, encontra-se em um sistema que prestigia a equidade e a boa-fé nas relações.

Assim, como bem concluído por Orlando Gomes (1967, p. 95), há três razões principais para as quais se deve aplicar a teoria da aparência: “1) para não criar surpresas à boa-fé nas transações do comércio jurídico; 2) para não obrigar os terceiros a uma verificação preventiva da realidade do que evidencia a aparência; 3) para não tornar mais lenta, fatigante e custosa a atividade jurídica."

É inegável, entretanto, que, em uma situação aparente, a vontade de quem erra, de boafé, prevalece sobre o direito do verdadeiro titular, como se houvesse efetivamente a realidade jurídica e não apenas a aparência. Logo, em regra, a aparência de direito produz os mesmos efeitos da realidade jurídica.

De qualquer forma, seja por meio das hipóteses preceituadas no ordenamento jurídico brasileiro, seja por meio da aplicação principiológica da aparência de direito, é inegável que o instituto tenha reflexos em todos os ramos do Direito pátrio, inclusive no vasto campo do Direito de Família, em que é relevante a sua aplicação em casos envolvendo o casamento aparente, como será tratado a seguir. 


\section{O CASAMENTO APARENTE}

Vitor Frederico Kümpel (2007, p. 315) define o casamento aparente como "aquele que se apresenta aos olhos do terceiro de boa-fé como se existente, válido e eficaz, fosse, porém, sem o ser, produzindo, todavia, efeitos patrimoniais onerosos válidos, em face da boa-fé gerada, pela confiança legítima e diligência do terceiro que com o casal aparente praticou o negócio jurídico".

O conceito em questão foi estabelecido com base no próprio dispositivo do art. 1.563 do Código Civil, que dispõe, in verbis: "A sentença que decretar a nulidade do casamento retroagirá à data da sua celebração, sem prejudicar a aquisição de direitos, a título oneroso, por terceiro de boa-fé nem a resultante de sentença transitada em julgado".

O Código Civil de 1916 não continha dispositivo similar que tratasse dos efeitos que poderiam advir do casamento putativo, a partir de seu reconhecimento por decisão judicial, em relação a terceiros que eventualmente adquirissem direitos, a título oneroso, do casal que aparentava estar casado sob o manto de um casamento válido e eficaz e que, em muitos casos, apresentasse a terceiros até mesmo uma certidão de casamento formalizadora do vínculo.

A omissão legislativa, durante muitos anos, deixou à margem situações que poderiam prejudicar o interesse de terceiros envolvidos em tal situação aparente, derivada de um negócio jurídico oneroso celebrado com os cônjuges entrelaçados em um matrimônio válido, em clara contrariedade à confiança e à boa-fé presentes na relação jurídica em questão.

E, assim, mesmo antes de o ordenamento jurídico brasileiro ter sido contemplado com a nova regra que protege a aquisição de direitos pelo terceiro de boa-fé envolvido em tal situação aparente, a doutrina já encontrava uma solução baseada na aparência de direito, ${ }^{27}$ como se nota no escólio de Yussef Said Cahali (1979, p. 175), que analisou a questão antes da vigência do novo diploma legal civil. Veja-se:

Dêsse modo, se os cônjuges de boa-fé invocam as convenções matrimoniais contra um terceiro, êste poderá invocar contra os esposos as consequências indivisíveis dessas convenções.

Mas se os cônjuges, ou cônjuge, por preferência se ativerem aos efeitos da nulidade, e, malgrado a boa-fé, desprezam as convenções matrimoniais (faculdade que lhes é formalmente reconhecida), então o casamento putativo não produzirá efeitos que consistam exclusivamente em direitos de terceiros contra os cônjuges.

Entretanto, com isto poderá ocorrer que, renunciando o cônjuge de boa-fé ao favor da putatividade, ou tendo o terceiro contratado com o cônjuge de má-fé, êsse terceiro venha a sofrer graves prejuízos consequentes da nulidade do matrimônio, no que se anulam os

27 No mesmo sentido, Orlando Gomes (1968, p. 111) já ensinava, in verbis: "O casamento putativo ainda produz efeitos, em relação a terceiros, sejam sucessores a título universal, ou a título singular. Podem êles se prevalecer do caráter putativo do casamento para exercer direitos que adquiriram na suposição de se tratar de casamento válido, mas como observam os MAZEAUD, nisso não há mais do que simples aplicação da teoria da aparência". 
negócios jurídicos estabelecidos com um ou com outro dos cônjuges.

E CRISAFULLI demonstrou quanto um resultado assim revela-se inquietante à segurança do comércio; daí porque se considera grave a lacuna do código, no que descuidou de disciplinar a respeito.

Em razão do que, e para supri-la, é válido o recurso à teoria da aparência, a fim de se determinar justamente até que ponto e em que medida, terceiros podem se prevalecer contra os esposos, da putatividade, de seu casamento, deferindo-se-lhes direitos que adquiriram na suposição de tratar-se de casamento válido.

É, pois, relevante e necessária a distinção entre o casamento aparente e o casamento putativo.

Como já esclarecido no capítulo anterior, o casamento putativo é aquele "nulo, ou anulável, que, contraído de boa-fé por ambos ou pelo menos, um dos esposos, tem, em razão dessa boa-fé, efeitos civis reconhecidos por ele" (CAHALI, 1979, p. 3).

Em análise ao conceito, percebe-se que os requisitos, já referidos, são: $1^{\circ}$ ) um casamento existente, ${ }^{28}$ que apresenta um vício de nulidade ou anulabilidade; $2^{\circ}$ ) a boa-fé de ambos ou, pelo menos, de um dos esposos; $3^{\circ}$ ) o erro de fato ou de direito; $4^{\circ}$ ) uma declaração judicial de invalidade do casamento.

Por outro lado, o casamento aparente, que apresenta como requisitos, segundo a regra constante do art. 1.563 do Código Civil: a aquisição de direitos onerosos pelo terceiro de boa-fé e a sentença que invalida o casamento, com efeitos ex tunc, é um reflexo da teoria da aparência no campo do Direito de Família e, como tal, sujeita-se a outros pressupostos de incidência da aparência, que são bem delineados por Kümpel (2007, p. 317), a saber:

$1^{\circ}$ ) exteriorização do casamento por meio da certidão de registro civil;

$2^{\circ}$ ) negócio jurídico, envolvendo de um lado, os cônjuges e, de outro, um terceiro de boa-fé;

$3^{\circ}$ ) incidência da boa-fé subjetiva e objetiva, a primeira pelo desconhecimento de vícios, e a segunda, pela exteriorização da própria relação aparente;

$4^{\circ}$ ) o nexo de causalidade estabelecido pelo negócio jurídico oneroso;

$5^{\circ}$ ) o significado econômico da relação aparente, ou seja, as duas partes envolvidas, a saber, o casal e o terceiro de boa-fé, tem ganhos e perdas nas relações jurídicas em questão.

\footnotetext{
28 Sempre foi muito controvertida a questão sobre a incidência da putatividade sobre o casamento inexistente. Grande parte dos doutrinadores civilistas, dentre os quais Washington de Barros Monteiro (1960, p. 106); Yussef Said Cahali (1979, p. 61); Cristiano Chaves de Farias e Nelson Rosenvald (2014, p. 251), dentre outros entendem que não pode ser putativo o casamento inexistente, uma vez que sequer chegou a se formar juridicamente, não tendo nem mesmo ingressado no ordenamento jurídico, o que aliás restou expressamente não contemplado no art. 1.561 do Código Civil. Por outro lado, uma segunda corrente doutrinária formada por civilistas como Sílvio de Salvo Venosa (2003, p. 118); Renata Barbosa de Almeida e Walsir Edson Rodrigues Júnior (2012, p. 148) defende que deve haver certa mitigação à regra de que o inexistente nunca gera efeitos, na medida em que, em alguns casos específicos, o direito deverá proteger efeitos gerados pelo casamento inexistente. Tratando do tema (FIUZA. Direito civil: curso completo, 2014, p. 1.059), propusemos uma reflexão, in verbis: "A teoria do casamento putativo abrange o casamento defeituoso, passível de anulação. Há quem defenda que também abrangeria os casos de casamento inexistente. Por exemplo, um indivíduo que se casasse enganado com um transexual, acreditando tratar-se de uma mulher. Os que se posicionam contra a ideia alegam que se o casamento é inexistente é porque não existe. E como pode ser algo não existente tratado como existente? De fato, do ponto de vista lógico-formal, têm toda razão. A questão que se impõe responder é: até que ponto a lógica formal deve ser sempre imposta ao Direito? Não haveria uma lógica jurídica menos tendente à lógica formal e mais à justiça?
} , 
Assim, como mencionado, com propriedade, pelo autor paulista, o casamento aparente independe da boa-fé dos cônjuges, porque ainda que tenham os dois obrado de má-fé no momento do casamento, com plena ciência do vício que maculava o matrimônio, ainda assim poderá haver a incidência do casamento aparente, no momento em que celebrarem negócio jurídico oneroso com um terceiro, apesar de não se falar, no caso, em putatividade do casamento.

No mesmo sentido, ao se referir aos negócios jurídicos onerosos, em comentários à regra do art. 1.563 do Código Civil, Luiz Edson Fachin (2003, p. 197-198) entende ter sido acertada a solução apresentada pelo legislador, ao não submeter o terceiro à insegurança que poderia decorrer da necessidade de um exame da situação atinente à boa ou má-fé da pessoa que com ele contrata.

E, ademais, a putatividade do casamento gera efeitos inter partes, ou seja, em relação aos nubentes, como já salientado no capítulo antecedente, que se refere ao direito à sucessão, aos alimentos, à meação e outros efeitos patrimoniais e, também, em relação aos filhos. Por sua vez, o casamento aparente apresenta efeitos diversos relacionados ao terceiro envolvido na situação aparente.

Como exemplo, pode-se mencionar uma situação em que um homem e uma mulher, que já eram casados em outras cidades, resolvem casar um com a outro e, apesar de viajarem constantemente para encontrar, cada qual, com a sua família originária, aparentam estar realmente casados perante a sociedade local. Passado certo tempo, com clara má-fé, decidem vender um apartamento que adquiriram juntos e que era desconhecido dos outros familiares. Todavia, descoberta a bigamia, os parentes ajuízam demanda direta de nulidade do casamento com eficácia ex tunc, tendo em vista o impedimento que viciou o matrimônio celebrado posteriormente, e requerem seja reconhecida a ineficácia da compra e venda do imóvel celebrada com o terceiro.

No caso em questão, não há falar em putatividade entre os novos cônjuges que praticaram a bigamia, uma vez que não estavam de boa-fé no momento da celebração do casamento. Todavia, trata-se de caso de casamento aparente, uma vez que será aplicada a aparência de direito, protegendo o direito do terceiro de boa-fé, que se viu envolvido na situação aparente e que agiu com erro escusável, tendo até mesmo consultado a certidão de casamento e acreditado que estava negociando com pessoas que haviam se casado de forma válida, nos exatostermos do art. 1.563 do Código Civil. Nesse caso, mesmo havendo a nulidade do casamento com eficácia ex tunc, retroagindo a sentença desde a data da sua celebração, haverá o sacrifício do direito da esposa enganada, que teria direito à meação do bem adquirido pelo outro cônjuge, em benefício do terceiro, prestigiando-se a boa-fé e a confiança como valores presentes nas relações jurídicas. 


\section{CONCLUSÃO}

A instituição familiar, no âmbito jurídico, não se manteve estática no tempo e no espaço, tendo o seu significado variado em consonância com as próprias transformações socioeconômicas que ocorreram ao longo da história da humanidade.

O casamento, concebido inicialmente como a única forma de constituição de estrutura familiar reconhecida pela Igreja e pelo Estado, caracterizava a grande influência que a religião exercia sobre a família, o que refletiu em seu grande prestígio no movimento de codificação ocorrida no século XIX, inclusive em relação ao Código Civil de 1916, sob forte influência da burguesia e marcado pelo patrimonialismo e patriarcalismo.

Com as mudanças sociais verificadas ao longo do século XX, especialmente após a promulgação da carta constitucional de 1988, dotada de valores como a solidariedade, igualdade, liberdade e dignidade da pessoa humana, alterou-se o antigo modelo unitário de família, que passou a ser o núcleo instrumental de desenvolvimento da personalidade dos membros e buscar a plena felicidade, fazendo com que o casamento se tornasse apenas uma das formas de constituição familiar.

Nesse contexto pluralista da família e considerando os novos paradigmas que ocorreram em relação ao direito privado no contexto do Estado Democrático de Direito, sobremaneira tendo em vista os princípios da socialidade, operabilidade e concretude que marcaram o próprio diploma civilista de 2002, assumiram especial importância os valores da boa-fé e da confiança que marcaram as relações jurídicas privadas.

$\mathrm{O}$ instituto do casamento putativo, enquanto teoria sistematizada, originou-se com os canonistas, nos séculos XI e XII, pelo qual, protegia-se a boa-fé dos nubentes (ou de um deles), ainda que o casamento fosse celebrado com vício de nulidade ou anulabilidade, especialmente em relação aos filhos. A partir do direito canônico, o instituto do casamento putativo foi assimilado por outros países do mundo ocidental, dentre os quais pelo Brasil, primeiramente através do Código Civil de 1916 e, posteriormente, por meio do Código Civil de 2002.

Por sua vez, a teoria da aparência ou aparência de direito, da qual se originou o casamento aparente, apresenta-se como um importante instituto descoberto pela doutrina ebaseado em valores amparados pela boa-fé e confiança, para a proteção dos negócios jurídicos que sejam implementados.

A própria concepção da teoria da aparência como um verdadeiro princípio a ser protegido pelo sistema jurídico ressalta a importância do tema, sobremaneira em relação ao campo do direito de família, o que, todavia, por envolver relações jurídicas, em que é afetado o direito do verdadeiro titular, demanda que o jurista sempre aja com cautela, quando deparar-se 
com uma situação de aparência de direito, devendo analisar, no caso concreto, todos os elementos e características do instituto.

Analisadas as características, elementos e efeitos do casamento putativo e do casamento aparente, verificou-se que há sensíveis diferenças entre os institutos, o que é de grande importância prática para a solução de diversos conflitos oriundos da invalidade de um casamento, seja em razão da nulidade ou da anulabilidade ocorridas na ocasião da celebração do matrimônio.

A proteção ao terceiro de boa-fé que se envolve em alguns casos de aquisição de direito, de forma onerosa, após a invalidação do vínculo matrimonial de uma das partes contratantes, no vínculo jurídico sinalagmático formado, deriva da aplicação da aparência de direito no campo do direito de família, sob a denominação do instituto do casamento aparente, que restou consagrada no direito positivo brasileiro, por meio da regra do art. 1.563 do Código Civil.

Dentro de tal contexto, a eventual colisão de interesses envolvendo o direito dos nubentes, após o reconhecimento da putatividade do casamento e também o choque entre o direito de um casal e/ou de parentes e o direito de um terceiro de boa-fé que se viu envolvido numa situação aparente, sempre deverá ser objeto de profunda análise, no caso concreto, com olhar atento nas características, elementos e efeitos próprios de cada um dos institutos, de modo a valorizar a necessária sistematização jurídica com critérios científicos importantes para a solução dos conflitos, garantindo a paz social.

\section{REFERÊNCIAS}

ALMEIDA, Renata Barbosa de; RODRIGUES JÚNIOR, Walsir Edson. Direito civil: famílias. 2. ed. São Paulo: Atlas, 2012.

AMARAL, Francisco. Direito civil : introdução. 7. ed. Rio de Janeiro : Renovar, 2008.

BORGUI, Hélio. Teoria da Aparência no Direito Brasileiro. São Paulo: Lejus, 1999.

BRASIL. Superior Tribunal de Justiça. Resp. $n^{\circ}$ 69.108. Relator: Min. Nilson Naves. Distrito Federal, Brasília, 27 mar. 2000.

CAHALI, Yussef Said. O casamento putativo. 2. ed. São Paulo : Editora Revista dos Tribunais, 1979.

CARVALHO SANTOS. João Manoel. Código civil interpretado. 2. ed. Rio de Janeiro: Freitas Bastos, v. IV, 1937.

CHAVINHO, Mateus Bicalho de Melo. A teoria da aparência e seus reflexos no direito brasileiro. Belo Horizonte: D’Plácido, 2014.

COULANGES, Fustel. A cidade antiga. Lisboa: Livraria Clássica, 1950. 
DE-MATTIA, Fábio Maria. Aparência de representação. São Paulo: Rumo, 1984.

DIAS, Maria Berenice. Manual de direito das famílias. 4. ed. São Paulo: RT, 2007.

DINIZ, Maria Helena. Curso de direito civil brasileiro: direito de família. 28. ed. São Paulo: Saraiva, 2013.

ESPÍNOLA, Eduardo. Anotações ao código civil brasileiro: direito de família. Rio de Janeiro, 1922.

FARIAS, Cristiano Chaves de. ROSENVALD, Nelson. Curso de direito civil: direito das famílias. Salvador: Juspodivm, 2014.

FERREIRA, Aurélio Buarque de Holanda. Pequeno dicionário brasileiro da língua portuguesa. 10. ed. São Paulo: Companhia Editora Nacional, 1972.

FACHIN, Luiz Edson; RUZYK, Carlos Eduardo Pianovsky. Direito de família: casamento. In AZEVEDO. Álvaro Vilhaça (Coord.). Código civil comentado. São Paulo: Atlas, 2003, v. 15.

FACHIN, Rosana Amara Giardi. Em busca da família do novo milênio. Rio de Janeiro: Renovar, 2001.

FIUZA, César. Direito civil: curso completo. 17. ed. São Paulo: RT, 2012.

GOMES, Orlando. O novo direito de família. Porto Alegre: Fabris, 1984.

GOMES, Orlando. Aparência de Direito. Transformações Gerais do Direito das Obrigações. São Paulo: RT, 1967.

GURGEL, Fernanda Pessanha do Amaral. Direito de família e o princípio da boa-fé objetiva. Curitiba: Juruá, 2012.

HOUAISS, Antônio; ILLAR, Mauro de Salles. Dicionário houaiss da língua portuguesa. Rio de Janeiro: Objetiva, 2001.

KÜMPEL, Vitor Frederico. Teoria da aparência no código civil de 2002. São Paulo: Método, 2007.

LIMA, F.A. Pires de. CRUZ, G. Braga da. Direito de família. 3. ed. Coimbra : Editora Limitada, v. I, 1949.

LÔBO, Paulo Luiz Netto. A repersonalização das relações de família. Revista Brasileira de Direito de Família. Porto Alegre: Síntese, IBDFAM, v. 6, n. 24, p. 143-144, jun/jul., 2004.

MALHEIROS, Álvaro. Aparência de Direito. Revista de Direito Civil, Imobiliário, Agrário e Empresarial. São Paulo, n. 7, out. 1978.

MAZEAUD, Henri. La maxime 'error communis facit jus'. Révue Trim. de Droit Civil, vol. 23, 1924.

MINAS GERAIS. Tribunal de Justiça. Apelação Cível 1.0000.00.219360-5/000. Relator: Des. Kildare Carvalho. Minas Gerais, Belo Horizonte, 22 nov. 2001. 
MONTEIRO, Washington de Barros. Curso de direito civil: parte geral. São Paulo: Saraiva, 1958.

MOREIRA GUIMARÃES, Octávio. A boa-fé no direito civil brasileiro. 2. ed. São Paulo: Saraiva, 1953.

PARANÁ. Tribunal de Justiça. Apelação Cível no 8.858, 28-1. Relator: Des. Wilson Reback. Paraná, Curitiba, 28 jan. 1994.

RÁO, Vicente. Ato Jurídico. São Paulo: Max Limonad, 1978.

RIZZARDO, Arnaldo. Teoria da Aparência. Revista da Associação dos Juízes do Rio Grande do Sul-AJURIS. Rio Grande do Sul, vol. 24, p. 223-231, 1982.

RODRIGUES, Sílvio. Direito civil: direito de família. São Paulo: Max Limonad, 1962.

SANTOS, Eduardo dos. Direito de família. Coimbra: Almedina, 1999.

SÃO PAULO. Tribunal de Justiça. Apelação Cível no 64.425-4. Relator: Des. Marcondes Machado. São Paulo, São Paulo, 05 mai. 1998.

SILVEIRA, Alípio. O casamento putativo no direito brasileiro. São Paulo: Universitária de Direito, 1972.

VENOSA, Sílvio de Salvo. Direito civil: direito de família. 3. ed. São Paulo: Atlas, 2003. 